\title{
SIMULACRO E IDEIA DE PLATÃO À PSICANÁLISE
}

\author{
$*$ \\ Pedro Sobrino Laureano \\ Universidade Federal de São João del-Rei - UFSJ - Brasil
}

\section{Resumo}

Buscamos, neste artigo, desenvolver a questão acerca da filiação platônica da psicanálise freudiana e lacaniana. Desta maneira, nossa primeira tarefa é questionar a imagem de Platão como filósofo dogmático, preocupado com a transcendência da Ideia e desprezando a singularidade sensível. Pelo contrário, veremos como é através de uma contradição imanente à filosofia platônica que podemos compreender como a psicanálise podes ser filiada ao projeto platônico, mas apenas se admitirmos que a verdade do discurso de Platão aparece em suas falhas inerentes. Procuraremos delinear o espaço da verdade na psicanálise como sendo causado pelo encontro com o que Lacan chamou de real, buscando compreender as relações do real com o platonismo. Nosso objetivo é questionar o anti-platonismo que constitui o paradigma social e filosófico do mundo contemporâneo, buscando em Platão e na psicanálise formas de se questionar o fantasma.

Palavras-chave: Platão; psicanálise; verdade; real.

\section{Introdução}

A filosofia do século XX pode ser caracterizada por seu anti-platonismo. Talvez, ao lado de Platão, seja apenas em Hegel que encontramos um autor repudiado por todas as correntes não apenas filosóficas como também políticas, do século XX. De maneira que, em um livro influente sobre Freud, Garcia-Rosa argumenta que:

\footnotetext{
O Mundo das Ideias foi substituído pela Subjetividade, o Cogito substituiu o Topos Uranos, mas em ambos os casos trata-se de determinar o lugar onde as cópias encontram os seus modelos e de onde os simulacros devem ser expulsos. (...) Por maiores que sejam as diferenças entre Descartes e Freud ou entre Locke e Hegel, todos são platônicos (GARCIA-ROSA, 2009, p. 10).
}

De fato, desde ao menos Nietzsche (1992) e Heidegger (1995) a filosofia moderna buscou, explicitamente, uma saída à problemática platônica, que seria também uma saída para a consumação do platonismo na filosofia de Hegel (BADIOU, 1992, p.97). Não apenas a chamada filosofia continental, mas também as filosofias analíticas e o pragmatismo elegeram a metafísica platônica e o idealismo hegeliano como os adversários a serem combatidos. E, finalmente, no dicionário filosófico encomendado por Stalin, no verbete Platão, podemos ler “ideólogo dos proprietários de escravos" (BADIOU, 1992, p.98). Mas, segundo Badiou, 
talvez um dos únicos filósofos hoje que pede um retorno a Platão, "ser curado do platonismo é ser curado da verdade" (Badiou, 1992, p. 100).

Qual a posição da psicanálise em relação ao anti-platonismo? Independente da declaração de Lacan, feita no contexto preciso da análise do Parmênides (2009) no Seminário XIX, de que "Platão era lacaniano" (LACAN, 1971-1972), há outros fortes indícios de que a psicanálise se filiaria ao projeto platónico. A simples questão colocada por Lacan aos analistas no Escrito A ciência e a verdade pode nos colocar na pista: (...) sim ou não (...) a verdade do sofrimento neurótico é ter a verdade como causa?” (LACAN, 1966/1998, p.885). Ora, a resposta de Lacan é mais complexa do que pode parecer à primeira vista.

Se, de fato, até os anos 70, a questão da verdade deveria ser mantida pela análise, compreendida como articulação simbólica da verdade recalcada do sujeito, a partir dos anos 70, Lacan enfatiza um polo que havia negligenciado da experiência analítica, aquele do gozo e do real. Ora, estes estariam para além da verdade, mesmo a simbólica. Conceitos como os de real não representável, gozo e sexualidade feminina constituem tentativas de pensar uma dimensão da experiência irredutível à nomeação simbólica e ao reconhecimento intersubjetivo. É entre estas duas dimensões do pensamento lacaniano, a do gozo e a do significante, a da pulsão e a da dialética de reconhecimento, então, que podemos colocar nossa questão: de que maneira a psicanálise, ao menos em Freud e Lacan, permanece dentro das coordenadas abertas por Platão?

Procuraremos argumentar, neste artigo, que Freud e Lacan ainda podem ser pensados como herdeiros do projeto platônico, compreendido fundamentalmente como o projeto de dissolução do fantasma e do encontro com o real, e que tal conclusão traz algumas consequências importantes para a compreensão não apenas da crítica psicanalítica ao poder contemporâneo, como também à própria clínica. Pois se Lacan, retornando a Freud, reconhece o campo do gozo e do real como sendo aquele que se coloca além da questão da verdade, admite, no mesmo passo, que a aposta da psicanálise é realizada na possibilidade de inscrição do real, através do qual o sujeito é capaz de proferir a verdade do gozo que o descentra.

\section{Em torno de Platão}

Em seu nível manifesto a filosofia platônica parte de uma adesão incondicional à transcendência como princípio racional, uma decisão pela plena inteligibilidade do mundo. Os seres sensíveis são distribuídos hierarquicamente conforme a sua participação no Modelo, a Ideia (Eidos) como paradigma perfeito. A empiria é o efeito distanciado, imperfeito, de uma 
Causa agente do universo, o Summun Bonum. A ideia de Platão é a de que o sujeito pode rememorar a Ideia, e que tal trabalho de rememoração já é a ação do princípio racional na alma. A acesse filosófica, a vida conforme a filosofia consiste na reapropriação racional da Ideia (Platão, 2003).

Entretanto, um paradoxo acomete a filosofia platônica, paradoxo plenamente articulado em seus diálogos do meio período como o Sofista (2007) e o Parmênides (2009): quanto mais o sujeito se purifica, aproximando-se das regiões ontológicas supremas, mais aquilo que ele combate — o simulacro, a cópia, o acidente sensível— parece torna-se estranhamente próximo da própria Ideia. A Ideia, como a exceção que cria a totalidade racional e permite ordenar o conjunto dos entes sensíveis, torna-se ela mesma excessiva. Se o caminho da purificação racional é manchado pela impureza, não se trata, entretanto, de mera incapacidade subjetiva em se aproximar da Ideia, ou da tentação exercida pelo mundo dos sentidos. Pois não seria justamente quando o sujeito é bem sucedido na ascese filosófica que o acidente, a cópia e o simulacro reaparecem dentro do próprio Universal? Dentro do próprio discurso purificado da razão, portanto, como sua loucura interna, o resto que distorce o quadro racional do mundo. Não deixando, entretanto, de pertencer a este mesmo quadro.

Em Platão a Ideia como princípio coloca-se do lado da participação (Badiou, 1988). Ela permite a participação, a elevação das cópias, mas não se compreende como ela mesma, a Ideia, se eleva. Como mostra Badiou, isto acarreta em uma divisão interior a Ideia, entre o Um e o Ser. Se definirmos a Ideia através do Ser, seu caráter como Una termina por escapar, ela perde-se nos múltiplos sensíveis que são. Se, pelo contrário, a apreendermos como Una, perdemos o Ser, a Ideia torna-se infinitamente distante do mundo sensível, afastada do Outro, das cópias imperfeitas às quais ela deveria se "aplicar". Ao mesmo tempo em que conserva a unidade da Ideia como o princípio primeiro, é principalmente ao lado de sua operação, de seu ser, que esta aparece na dialética platônica. A Ideia produz as distinções que operam a distribuição dos seres, mas nunca apreendemos a Ideia como tal, não contaminada por aquilo que ela medeia. Como dizia Antístenes, em sua crítica cínica de Platão, vemos cavalos, mas não vemos a "Cavalidade", a Ideia eterna de cavalo (SAFATLE, 2008, p. 155).

Ora, esta disjunção interior à Ideia, entre Ser e ser $U m$ implica que abordemos a filosofia platônica em dois níveis, o da participação, na qual ela é o Modelo que se aplica às cópias, e o da transcendência da Ideia, na qual o Modelo apenas comtempla a si mesmo. Se estes dois níveis forem concebidos como inerentes à própria Ideia, a síntese platônica entre o devir heraclitiano e o Ser dos Eleatas torna-se uma síntese fracassada, pelo fato de que a Ideia se deixa dividir, sendo afetada por uma passividade fundamental, uma espécie de impotência. 
De fato, o objetivo manifesto de sua filosofia é reconhecer a necessidade de construir uma conexão racional entre o mundo sensível do devir ilimitado heraclitiano e o mundo inteligível do Ser da escola Eleata. Ao contrário dos Eleatas, deve-se pensar a Ideia como operando no mundo sensível. Mas, em oposição a Heráclito, deve-se pensar o mundo sensível como submetido a um princípio Racional, sob o risco de se perder a condição mesma do discurso.

Se o papel da Ideia como fundamento da mediação falha, então, se a síntese entre o sensível e o inteligível não puder ser pensada, o projeto platônico fracassa. Ora, é para tal fracasso que Badiou aponta, quando chama atenção para a tensão irredutível na filosofia platônica entre o Um e o Ser, cujo resultado é uma cisão interior à própria Ideia:

\footnotetext{
É na própria ideia que encontramos o descompasso entre a suposição de seu ser (o lugar inteligível) e a constatação de um efeito de um que ela suporta ( a participação), puro "há" excedente de seu ser, em relação à apresentação sensível e as situações mundanas. (...) A ideia é—e por outro lado, "há um" a partir dela e fora dela mesma. Ela é seu ser, e também o não ser de sua operação (...). O um está somente no princípio de toda ideia, compreendido do lado de sua operação-de participação — e não de seu ser (BADIOU, 1988, p. 39).
}

A ideia suprema não pode ser definida segundo o princípio de Identidade, isto é, segundo o Um. Ela é uma pura operação de conta, aquilo que Lacan (1971-1972, p. 110) chama de Yad lun, um "há um" que não sobrevive fora de sua existência nos múltiplos seres que ela determina como unos, que ela estrutura. A essência do Um, então, é posterior a sua existência nos múltiplos que ele estrutura, um foco virtual, sempre suposto, reconstruído no $a$ posteriori do "há um" (Yad’lun) como operação, nunca verdadeiramente encontrada como pura abstração, mas sempre já manchado por aquilo que ela deveria purificar. De maneira que podemos nos perguntar, em termos psicanalíticos, se o objetivo inconsciente de Platão não seria justamente a recusa do encontro com a Ideia, isto é, o inverso da intenção manifesta de sua filosofia.

Mas porque, então, Platão fugiria do encontro com a Ideia? E porque tal fuga se daria pela forma de seu oposto-pela elevação do Uno a princípio primeiro, transcendente, mais real que o fantasma do mundo sensível? Para responder a estas questões será preciso, antes, passarmos pela relação entre a psicanálise e o platonismo.

\section{Significante e gozo}

De um lado, então, temos o Um sem o ser, o princípio inteligível sem sua operação; de outro, o ser sem Um, a operação de divisão que se deixa contaminar por aquilo que ela divide. 
Ora, a ideia de "Um sem ser" nos oferece uma das definições lacanianas do significante (ZIZEK, 2013, p. 42). Para Lacan, o significante opera a castração simbólica do ser, compreendida como o esvaziamento operado pelo simbólico do gozo substancial do corpo. Este se torna perdido, faltoso, sendo contabilizado como uma dívida que nunca poderá ser plenamente restituída ao simbólico. Se for assim, então, a ideia do "ser sem Um” relaciona-se ao que Lacan chama de gozo, àquilo que na filosofia de Badiou ganha o nome de "multiplicidade inconsistente" ou "múltiplo de múltiplos" (Badiou, 1988). Do gozo das pulsões parciais freudianas (anus, boca, voz, olhar) ao gozo ilimitado da jouissance feminine, trata-se do que Lacan se deu como tarefa pensar quando relativiza a centralidade do significante na análise, a partir dos anos 70, buscando no gozo aquilo que mancha a pureza transcendental da rede simbólica (LACAN, 1972-1973).

De fato, se Lacan alguma vez pensasse em identificar estes termos, o ser e o Um, eliminando o papel negativo, de disjunção, que um impõe sobre o outro e operando a síntese entre o discurso e o ser, significante e gozo, poderíamos dizer que o projeto lacaniano é platônico. Entretanto, isto é justamente o que Lacan não realiza. A verdade da relação entre o Um e o Ser é, para Lacan, a de uma "não relação", uma dissimetria, como no enunciado a respeito da impossibilidade da relação sexual ("não há relação sexual") (LACAN, 19721973). A aposta de Lacan é a de que o "ser sem Um" e o "Um sem ser" são duas expressões distintas de uma mesma operação, aquela da não reunião, da não relação entre o significante e o gozo.

No Um sem ser, a primazia do significante significa que o Um nasce da exclusão do ser. O significante implica a anulação do gozo, como não se cansou de dizer o Lacan estruturalista dos anos 50 (Lacan. 1954-1955). A partir do momento em que o sujeito fala, algo se perde, a referência externa é abolida e o nome passa a girar em torno de si próprio. Por outro lado, no ser sem Um é o gozo que resiste a sua inscrição na diferencialidade estruturada do significante, sua transformação em falta quando enquadrado pelo Um simbólico. Este próprio movimento auto-referencial da língua acarreta em um estranho prazer a mais que é ao mesmo tempo exterior e interior à fala, dos chistes, atos falhos e sintomas àquilo que Lacan chamou de "lalangue", a fala como forma de gozo, para além e mesmo contra a comunicação intersubjetiva (LACAN, 1973).

A conclusão de Lacan é que tal tensão, tal dissimetria, é irredutível. Tanto o significante quanto o gozo sempre aparecerão como excessivos ou faltosos, devido à ação do Outro. Quer este Outro seja associado à rede de significantes ou pensado, como tende a fazer Lacan a partir dos anos 70, como o Outro do gozo ilimitado, da jouissance féminine. A solução desta 
antinomia é, portanto, idêntica a sua formulação, a sua repetição, mas sem a ideia de que haveria uma síntese ou reconciliação entre gozo e significante.

Podemos recolar a questão, então: a psicanálise é platônica? A análise move-se dentro do espaço da verdade, ainda que tal verdade não seja mais associada ao projeto platônico da transcendência da Ideia? E agora podemos ver como a resposta a esta questão não é unívoca. Obviamente, Lacan não é platônico se associamos platonismo ao projeto explícito de Platão, o de pensar o não ser através da categoria do Ser, o sensível através do Inteligível, realizando a síntese entre Heráclito e os Eleatas. Por outro lado, ele é platônico exatamente aonde Platão fracassa, isto é, quando a disparidade entre o não ser do múltiplo sensível e o Ser da Ideia torna-se interior à própria Ideia.

Isto nos parece implicar, em termos do pensamento de Lacan, uma consequência importante, às vezes negligenciada pelos próprios psicanalistas lacanianos: quando introduz a tópica do gozo e do real, nos anos 70, é certamente verdade que Lacan atesta que o gozo ou o real não são da ordem da verdade. Isto é, o gozo não se deixa prender à dialética entre o verdadeiro e o falso, à dialética simbólica que faz verdade e ficção coincidirem dentro dos desconhecimentos e reconhecimentos da fala. Entretanto, o gozo, como "Ser sem Um", aquilo que Badiou chama de múltiplo de múltiplos, a multiplicidade que apenas pode ser predicada de si mesma, não deixa de constituir, para Lacan, uma condição do discurso. Isto é, ele não deixa de ser êxtimo, ao mesmo tempo interior e exterior ao espaço da verdade, à estrutura e ao Um significante, portanto. Como coloca Jaques Allain Miller,

\footnotetext{
Há um gozo opaco que exclui o sentido e que apareceu a Lacan no final. Cabe guarda-lo. Há um gozo insubmisso, rebelde, incompatível aos olhos da estrutura da linguagem e que não se deixa significar. Quando o analista tem de se haver com este gozo, ele só pode, precisamente porque faz falar, recorrer ao sentido, dar sentido ao gozo. E o sentido que ele dá definitivamente é sempre edipiano ou, pelo menos, é sempre paternal (MILLER, 2011, p. 190).
}

De maneira que a questão da análise é: "será que o gozo de impossível negativização é um problema a resolver?” (p. 190). E, da mesma forma, o final da análise pode ser relacionado a um "sim à contingência que me fez o que sou" (MILLER, 2011, p.190), isto é, um sim ao gozo em seu caráter ao mesmo tempo excessivo e faltoso, idiossincrático. Ora, isto implica que o final de análise, aquilo que Lacan, pensando sua escola, chama de passe ( $c f$. Lacan, 1968/2003), não seja nem resolvido pelo lado do gozo, nem pelo simbólico, mas através da não relação entre simbólico e real. Pois se o gozo não diz nada, não é da ordem do 
sentido, trata-se de proferir sobre ele uma afirmação simbólica que, como coloca Miller, sempre se opera pelo lado do complexo de Édipo, isto é, da interdição simbólica.

Entretanto, a respeito de que interdição se trata, aqui? Tudo indica que lidamos com uma interdição reflexiva, isto é, que recai na própria função interditora, o simbólico, como na escrita de Lacan (1972-1973) do significante do Outro barrado. Lacan, desta maneira, buscar pensar um discurso capaz de reconhecer na contingência radical do gozo aquilo que não pode ser negativizado em termos de oposições simbólicas. E aqui o complexo de Édipo, como operação da Lei simbólica, chega ao seu limite através do reconhecimento de seu fracasso fundamental em mediar o gozo que supostamente ele deveria proibir. A Lei simbólica cria a falta que negativiza o gozo, mas também o excesso que o torna transgressor. O significante é divido pelo gozo proibido, já que é a proibição que cria aquilo que é proibido, e o excesso que se pretenderia eliminar é interior ao próprio símbolo (LACAN, 1959-1960).

Talvez seja interessante, aqui, recorrer a Hegel. Tanto a respeito do Ser em Um quanto do Um sem Ser, da multiplicidade inconsistente do gozo ou do significante estruturado, o conceito hegeliano de "negação determinada" (HEGEL, 2011) pode nos ajudar a pensar este regime de inadequação que caracteriza a não relação entre ser e discurso. Para Hegel, trata-se de afirmar que o negativo retorna dentro do positivo, como seu núcleo descentrado. Se retirarmos ao discurso de Hegel a ideia de síntese como sendo a do retorno à identidade através da mediação com a não identidade ou, em termos lacanianos, da sutura do gozo através de seu reconhecimento simbólico, dialética e psicanálise parecem, como argumentam filósofos como Zizek (2013) e Safatle (2008), aproximarem-se em pontos cruciais. A consequência é que tanto o gozo como o significante são barrados, mas a barra funciona de forma "ativa", de maneira que é a não relação que os relaciona.

$\mathrm{O}$ antagonismo entre gozo e significante marca o próprio pensamento de Freud e de Lacan. Na interpretação de suas obras, uma das tentações que nos parece dever ser evitada é a de buscar um Freud ou um Lacan "corretos", ou verdadeiros. Seriam aqueles da primeira tópica freudiana e da aposta lacaniana no simbólico, da elaboração psíquica do trauma e da dialética do reconhecimento? Ou, antes, deveremos buscar a verdade da psicanálise na segunda tópica freudiana e na aposta lacaniana no real, onde ambos buscaram reconhecer um limite para a elaboração psíquica, na forma do gozo da pulsão? Ora, a única resposta possível não nos parece ser escolher entre um ou outro, mas sim afirmar a não relação entre ambos, transpondo a ruptura teórica como já sendo imanente à própria teoria.

Então, em resposta à pergunta “a psicanálise é platônica?", podemos fornecer a resposta: sim, mas no momento preciso em que Platão fracassa. É que tal fracasso de Platão 
não é apenas negativo. Pois, de certa forma, trata-se de fracasso que continua sendo interior ao espaço aberto por Platão, este que, de fato, é consumado na filosofia de Hegel, que é o espaço da aposta pela inteligibilidade do real. "O real é racional, o reacional é real”, como coloca Hegel no Prefácio a filosofia do direito (1997), em um movimento que talvez tenha seu início quando Platão buscou trazer à razão aquilo que o Ser dos Eleatas havia negligenciado, o não ser do simulacro ou das cópias. É apenas a partir deste impulso de univeralização que surge a exceção-ou deveríamos dizer o sintoma?-platônico. Exceção que retorna dentro da Ideia já que, da Ideia como exceção que estrutura a representação do mundo sensível, nos leva ao excesso inerente à própria Ideia.

É o caráter produtivo da não relação entre gozo e discurso que não pode aparecer, ainda, na filosofia platônica, ou ao menos no discurso manifesto de sua filosofia. Certamente, não se trata da ideia do senso comum de que o erro é parte fundamental no caminho da verdade, mas que, uma vez tendo feito sua parte, ele deveria em seguida desaparecer. Pois não lidamos aqui apenas com fracassos empíricos, ônticos, mas sim com um fracasso elevado ao estatuto da Verdade, o fracasso na constituição da própria Verdade, que nasce não por alguma deficiência da razão, mas sim por sua universalização. Se, como coloca Deleuze, "o mundo heraclitiano" do devir "freme sob o platonismo" (DELEUZE, 1968, p.97), é porque tal mundo, aparentemente domesticado pelo postulado da Ideia, retorna triunfante nas aporias internas do conceito platônico central. E a verdade de tal retorno se enuncia, à revelia do discurso manifesto, nas tentativas de Platão de excluir as inconsistências de sua teoria. Ele aparece em suas soluções de compromisso e na persistência do fantasma, no recurso ao mito em momentos cruciais de sua filosofia, como na alegoria da Caverna e no Mito de Er em $A$ república (PLATÃO, 1993). Ora, tais aporias, longe de atestarem a incapacidade de Platão, nos parecem constituir a prova de que seu discurso, de fato, aproxima-se da verdade.

\section{Porque Platão era lacaniano?}

Retornemos a Platão, portanto. Conforme vimos anteriormente, podemos dizer que é o afastamento da Ideia o verdadeiro alvo de seu combate aos simulacros. A Ideia mantém uma distância fantasmática, patente no recurso platônico ao mito sempre que se trata compreendêla para além da maneira através da qual ela age no mundo sensível. E o mito sinaliza para a finitude do conhecimento humano, via amplamente explorada, do neoplatonismo ao discurso religioso. Se o princípio de inteligibilidade é, nele mesmo, ininteligível, é devido à 
proximidade ôntica do sujeito com as cópias e os simulacros, e não por uma inconsistência interna inerente à própria razão, ao Universal como tal.

Como se Platão precisasse fixar-se nas “preliminares", isto é, na operação da Ideia, mas o verdadeiro objetivo de sua filosofia, como argumenta Deleuze em Diferença e repetição (1968), fosse polêmico, mundano: o combate ao sofista, à cópia sem semelhança, naquilo que Deleuze chama de a "seleção dos pretendentes" (p. 98). O que importa, afinal, o Um? Se tal fixação nos pretendentes tem por tarefa excluir o encontro com a Ideia é porque Platão recua, não aceita enxergar que a Ideia já é nela mesma dividida por aquilo que ela deveria mediar. Se a exclusão dos simulacros e a seleção das boas cópias que guardam semelhança com a Ideia constitui o motivo manifesto de sua filosofia, o verdadeiro motivo, latente, inconsciente, que se realiza inteiramente na imanência do discurso platônico, através de suas inconsistências internas, é impedir o encontro com a impossibilidade de se dizer o próprio ser do Um. Ou, em termos lacanianos, com a impossibilidade de se relacionar o significante e o gozo.

Platão precisa do simulacro para combatê-lo, assim como precisa do sofista como seu Outro constitutivo, deslocando o conflito interior à Ideia para um conflito entre a Ideia e seu Outro exterior, o antagonismo interior ao próprio Um para um conflito entre o Um e a multiplicidade pura, o Um substancial e a "pura apresentação" (BADIOU, 1988) do múltiplo sensível. Pois é a impossibilidade de dizer o ser do Uno que o torna próximo do não ser atribuído por Platão aos simulacros. A invenção da ideia de cópia, então, pode ser pensada como sendo a "solução de compromisso" platônica, como a tentativa de reconciliar os opostos que Freud (1915/2006) associa ao sintoma. Ao articular o não ser dos simulacros e o ser do Um, a função da cópia é a de impedir, a qualquer custo, que o simulacro se torne interior ao próprio Um, como sua determinação negativa. Ao invés de ser salva pelo Um, de receber dele sua razão, é a cópia que termina por salvar o Um, impedindo que a própria exceção se universalize.

Sendo assim, o "assassinato do pai Parmênides", maneira através da qual se costuma caracterizar a hipótese desenvolvida no Parmênides (2009) de que o "Um não é", torna-se consubstancial ao projeto da filosofia platônica. O Parmênides, conforme as palavras de Zizek, é "mais radical do que os diálogos tardios de Platão, porque ele traz o colapso do grande Outro, revelando suas falhas e inconsistências" (ZIZEK, 2013, p. 42). O que corresponde à constatação, feita por Lacan no Seminário XIX (1971-1972) quando trabalha as aporias do Um a partir do mesmo diálogo platônico, de que "Platão era lacaniano". (p. 127). Ao apresentar a hipótese de que o Um não seja, o Parmênides revela como é inerente ao Um ser Outro. Não qualquer Outro, entretanto, mas o Outro do não ser, do "não Um”. Como 
coloca Lacan, “o Um começa no nível em que há um faltando” (LACAN, 1971-1972, p. 140), constituindo, assim, uma "pura e simples diferença" (p. 139). Não se trata de uma diferença externa, mas uma diferença inerente ao próprio Um. E se o Outro que divide o Um é ele mesmo enquanto faltante, o Um não é nada mais que o nome de sua falta (BADIOU, 1988).

Mesmo que apresentada como uma hipótese extravagante, a ideia de que "O um não é" é estruturalmente inscrita na filosofia platônica, na decisão pela racionalidade do real. Platão, aqui, apenas não segue até o fim seus próprios pressupostos, renunciando, em seus diálogos posteriores ao Parmênides e ao Sofista, a elaborar as consequências das teses entrevistas neste momento. Devemos estar atentos, então, que em relação ao anti-platonismo espontâneo de nossos tempos criticado por Badiou, não se trata de dizer que Platão confere poderes exagerados à razão, mas, pelo contrário, que ele erige um limite arbitrário a seu poder, fundando a razão através da exclusão de seu oposto, o não ser do simulacro. Este passa a ser interpretado como uma privação do Ser, não como uma negatividade determinada por sua relação com o próprio Ser, mas como um negativo apenas relativo, uma simples insuficiência contraposta à onipotência do Ser.

Naquilo que Deleuze chama de "subversão do platonismo" (DELEUZE, 1968) e que, de fato, encontra-se como um programa comum a toda filosofia do século $\mathrm{XX}$, não se trata de pensar a simples destituição do Um a favor da multiplicidade ou do simulacro, mas sim de mostrar como tal subversão já é imanente ao próprio platonismo, sendo aberta apenas pelo espaço que Platão ajudou a pensar, o espaço da correlação entre o real e o racional. O não encontro do Um consigo mesmo, seu auto-exílio, o tornar-se simulacro do Um e do tornar-se Um do simulacro, constituem a verdade da filosofia platônica. E, como coloca Badiou, a razão pela qual é fundamental, hoje-em uma época marcada pelos sofismo, pelo culto à finitude e à relatividade dos modos de vida — retornar a Platão.

\section{Palavras sem coisas, coisas sem palavra.}

Trata-se, então, de retornar à decisão platônica, como àquilo que permanece inconcluso em seu projeto, mas que pode ser reabilitado. De certa forma, retornar à decisão platônica será retornar à ideia do mundo real como sonho, simulacro ou fantasma. O que existiria, hoje, de mais contra intuitivo, de mais contrário ao senso comum do que afirmar que a realidade não passa de um sonho, que os homens acordam para continuar sonhando e que o real, o verdadeiro real, nós não o temos de fato, embora, segundo Platão, o possuímos em direito? 
A psicanálise, neste sentido, é de fato herdeira do impulso platônico da Verdade e da dissolução do fantasma. Entretanto, para ela é justamente através da fantasia e do sonho que se encontra o real. Como coloca Lacan sucintamente, "é a partir do discurso em que se funda a realidade da fantasia que aquilo que há de real nessa realidade se acha inscrito" (LACAN, p.478, 1973). Isto é, se o mundo não passa de um fantasma, se a própria realidade é estruturada de acordo com o fantasma, é nele, entretanto, que o real se apresenta e, com ele, também a possibilidade de inscrever a verdade deste encontro no mundo. Certamente, tal encontro é um desencontro, um encontro falhado (Lacan, 1973), e a escrita da verdade deste encontro falhado deverá, para utilizar o conceito de Badiou (1988), ser fiel à falha que nele se anuncia.

O real aparece, então, quando a realidade é enquadrada, arrancada de sua inércia para entrar no moinho da linguagem e esta, abolindo a referência natural ou exterior, começa a circular em torno de si mesma, repetindo sua própria impossibilidade. A função mais inquietante da ficção, sendo assim, não é a de mascarar a realidade, mas a de dar a ver que a realidade, tal como a experimentamos, já é uma máscara, uma ficção, não de algum real exterior, mas de si mesma. O real é a aparência postulada como aparência, sem a ideia de que haveria uma realidade por trás da ficção. Esta duplicação da aparência é, paradoxalmente, o que faz com que o fantasma da realidade possa dar lugar ao real, no sentido lacaniano: este não é nada mais do que a distância da aparência em relação a ela mesma, a divisão interna da aparência, quando ela não é nada mais do que a aparência de si mesma.

Por isto a eficácia de uma análise repousa inteiramente na aposta de que a narração ou historicização significante, longe de excluir o real, é condição de sua emergência. Uma forma de compreender tal ideia é através da regra fundamental da psicanálise proposta por Freud, a da "associação livre" (FREUD, 1900/2006). Ela significa que as interdições que estruturam a circulação de palavras no laço social serão suspensas dentro do espaço da análise. Entretanto, a ideia de Freud não é que a suspenção das interdições possa livrar o sujeito de seus constrangimentos, possibilitando que ele se desfaça do peso da moral e finalmente reconheça seus desejos enquanto individualidade livre. ${ }^{1}$ Pelo contrário, o que tal suspensão busca é atingir o ponto de impossibilidade imanente ao discurso do sujeito, a passagem de uma interdição meramente "ôntica", vivenciada no plano do conflito entre o indivíduo e as regras sociais que lhe constrangem, para uma impossibilidade ontológica, isto é, uma impossibilidade que concerne ao próprio ser do sujeito e do Outro "social".

A partir do momento em que o analista pede ao sujeito que diga tudo o que lhe vier à cabeça, o que se busca não é mera abolição do recalque, mas sim sua radicalização. Trata-se 
de chegar àquilo que Freud (1915/2006) chamou de recalque original, a exclusão inaugural que incide sobre a própria relação entre o sujeito e o Outro, e que retorna através dos sintomas $^{2}$. O sujeito necessariamente descumpre a regra fundamental da análise, aquela de tudo dizer, descobrindo que nem tudo pode ser dito, que há um limite para as palavras. Tal descumprimento, entretanto, não podendo mais ser imputável a uma interdição qualquer (já que, na análise, tudo é permitido falar), torna-se imanente ao próprio discurso.

É porque "não há metalinguagem" ou, segundo outro axioma de Lacan, porque "não há Outro do Outro" (LACAN, 1973), que a tentativa de tudo dizer esbarra em um ponto intrínseco de impossibilidade, em uma aporia estrutural. Ora, esta aporia, esta impossibilidade constitui, para Lacan, o núcleo do desejo, a causa que descentra o sujeito e o faz desejar. E esta passagem da repetição enquanto ato para a repetição simbólica na análise busca atingir tal ponto de impossibilidade, tornando a repetição "em si", que é vivida na dimensão da ação na realidade (sempre suportada pelo fantasma, segundo Lacan), em uma repetição "para si”, em que o real para além do fantasma é assumido simbolicamente pelo sujeito.

A suspenção analítica da proibição concerne somente ao dizer, buscando transpor para a linguagem, para a ficção, aquilo que o sujeito vive na forma do ato, da repetição insensata. $\mathrm{Na}$ análise, tudo poderá ser dito. Entretanto, tal desinflação do ato não significa que o sujeito passa a reconhecer, no meio bem temperado das palavras, aquilo que ele vivia como ação insensata, violenta. A palavra não constitui um meio capaz de aliviar a violência inerente à ação, contribuindo à homeostase dos excessos aos quais o sujeito se entrega. Pelo contrário, é a violência da realidade que constitui, antes, aquilo que Lacan chama de "passagem ao ato" (LACAN, 1962-1963): a fúria destrutiva que mascara a impotência do sujeito, sua tentativa de destruir o Outro como a consequência do reconhecimento da onipotência do Outro. É na ficção, no simbólico, que o sujeito se depara com uma violência muito mais aterradora do que a da realidade, a violência de seu desejo. Ao sair da repetição na forma do ato e repetir simbolicamente, o real da situação aparece, e o sujeito é capaz de assumir aquilo que se repete necessariamente como encontro falhado, como acaso reiterado.

Há, para a psicanálise, uma relação de não complementaridade entre teoria e praxis, entre as palavras e as coisas. A palavra necessariamente não encontra a coisa à qual ela corresponde, e a coisa, da mesma forma, nunca encontra a palavra que a nomearia. Segundo o argumento de Badiou em Logique des Mondes (2006), se nossa época caracteriza-se pelo "materialismo democrático", que afirma a imanência entre corpos e linguagens, entre palavras e coisas, o "materialismo dialético" adiciona que, além dos corpos e das linguagens, há a Verdade (2006, p. 29). Entretanto, para Badiou, a Verdade não constitui uma dimensão 
metafísica, transcendente, mas, como viu Platão em determinado momento, a própria disjunção entre corpos e linguagem.

O materialismo dialético não adiciona nada à realidade. Ou melhor, ele adiciona à realidade o próprio nada, o que Badiou chama de "nome do vazio" (1988). Sendo assim, ele adiciona algo que cancela o fantasma da reunião entre corpos e linguagem, um terceiro ausente que responde à própria disjunção, a não reconciliação entre ambos. Não se trata de um "x" como exceção transcendente à imanência dos corpos e da linguagem, mas de um "x" que impede sua relação harmônica. A tese psicanalítica (e platônica) de Badiou é, então, que corpos e linguagens, palavras e coisas não se reúnem, não formam um todo. E que tal destotalização é a condição para aquilo que, em sua filosofia Badiou chama de Evento, o encontro brutal do sujeito com a verdade (Badiou, 1988). A aposta na verdade é aquela de um sujeito capaz assumir a disjunção entre corpos e linguagens. De um sujeito que é, ao mesmo tempo, uma coisa sem nome e um nome sem coisa.

\section{O abismo da tolice}

Vimos como o resultado da metafísica platônica é que o próprio princípio racional absoluto torna-se inconsistente, e que devemos ver nesta inconsistência seu desejo inconsciente. Ao distanciar o Uno e suas exemplificações empíricas, suas cópias imperfeitas, Platão imobiliza a Ideia, mantendo-a a uma distância suficiente para que ela não produza efeitos "catastróficos" na realidade material. A metafísica platônica constitui, desta forma, o esforço para se salvar o mundo do encontro com aquilo que ela mesma inventa, a Ideia. Se seu objetivo manifesto é a tentativa de subordinar o mundo sensível ao Um abstrato, a consequência latente de seu discurso é a destituição do próprio Absoluto.

Obviamente, o objetivo manifesto da instituição do Absoluto metafísico não é sua destituição. Como aparece, então, o motivo "oculto", inconsciente? Ora, não em alguma intensão profunda, secreta, mas na forma mesma do discurso, ela aparece nas falhas imanentes do discurso platônico: a regressão infinita implicada no postulado platônico da Ideia - existe a Ideia da Ideia?-, mas também, devido ao próprio caráter totalizante da Ideia, o escanda-lo que consiste em seu admitir que, se tudo é Ideia, o próprio não ser - o sofista, o simulacro - deve ser, também, uma Ideia. E que, portanto, a Ideia é ela mesma e seu inverso. Isto é, ela é contraditória.

É o que vemos, no Parmênides (2009), em trechos em que o efeito cômico deve ser relacionado a esta inversão de lugares entre o mais alto e o mais baixo, a Ideia e o simulacro, 
que, como temos visto, assombra a filosofia platônica. Trata-se da questão dirigida por Parmênides a Sócrates, sobre se haveria a Ideia de coisas como pelos, lama ou sujeira:

\footnotetext{
"E estarias indeciso com respeito a outras coisas, que poderias taxar de ridículas, tais como pelos, lama, sujeira, ou qualquer outra coisa especialmente indigna e insignificante? (...)."

"De modo algum", disse Sócrates. "Penso que essas coisas são apenas o que vemos, e seria inteiramente absurdo crer que há uma forma delas. E, no entanto, às vezes sinto-me perturbado pelo pensamento de que talvez o que se aplica a uma coisa, se aplica a todas. A consequência é que, assumida essa posição, fujo receoso de me precipitar em algum abismo de tolice e me arruinar.” (PLATÃO, 2009, p. 37).
}

Ora, para a psicanálise a resposta à questão de Parmênides deve ser que sim, que há a Ideia de pelo, lama e sujeira, de objetos parciais e excrementos, do sexo e do gozo que divide o sujeito. Como coloca Lacan a respeito daquilo que chama A coisa freudiana, a prosopopeia da verdade, quando é a própria verdade que fala:

[Eu, a verdade] vagabundeio pelo que julgais como sendo o menos verdadeiro por essência: pelo sonho, pelo desafio ao sentido da piadinha mais gongórica e pelo nonsense do mais grotesco trocadilho, pelo acaso, e não por sua lei, mas por sua contingência(...) (LACAN, 1956/1998, p.411)

Este é o sentido, então, da universalização da razão que faz Sócrates confrontar o "Abismo da tolice" e recuar. Nietzsche, o filósofo anti-platônico por excelência, escreve em Além do Bem e do mal que "se olhares demasiado tempo dentro de um abismo, o abismo acabará por olhar dentro de ti." (NIETSZCHE, 1992, p.88), significando com isso que a dimensão profunda da verdade deve ser descartada a favor da inocência da vontade e da afirmação do simulacro. Talvez Nietzsche não tenha percebido, entretanto, o caráter tolo, cômico, que espreita a profundidade platônica.

Platão já enxergara o problema, entretanto, quando faz Sócrates falar que, "talvez, o que se aplica a uma coisa, se aplica a todas" (PLATÃO, 2009, p.37). Pois é apenas levando até as últimas consequências o postulado platônico da universalidade da razão, da igualdade racional do mundo, aquilo que Jacques Ranciére chama através do termo apropriado de "o axioma da igualdade" (2007), que a verdade deixa de ser a transcendência profunda de uma Ideia que subjuga a superfície, para se deixar atravessar pelo excesso do simulacro. É desta maneira que o axioma da igualdade platônico, longe de significar a identidade abstrata dos entes sensíveis perante uma Forma externa, passa a significar a coincidência entre igualdade e diferença que faz de dois entes iguais somente através de seus excessos. A Forma ou a Ideia, ao invés de subsumir um conjunto de elementos a partir de uma categoria abstrata, torna-se nela mesma 
deformada. Os seres que nela se refletem apenas recebem de volta seu sentido distorcido, excessivo, mas - e por isto mesmo- consistente.

Quando atingimos o ponto mais alto da hierarquia ontológica, o ser se despedaça e aquilo que ele deveria excluir retorna: a contradição. Em termos psicanalíticos, o fracasso da metafísica platônica torna-se, entretanto, a razão de seu sucesso. Para a psicanálise, a verdade de um discurso não está na intenção, mas no resultado, na imanência do dizer. Tal subversão imanente de um enunciado constitui uma das premissas do método psicanalítico. $\mathrm{O}$ inconsciente não é o núcleo profundo, o sentido oculto de um enunciado manifesto, mas a maneira como o enunciado subverte a si próprio no ato de sua enunciação (ZIZEK, 2013; FREUD, 1900/2006). Um enunciado não é subvertido devido a uma verdade mais elevada, sendo a tarefa do psicanalista justamente a de apagar a dimensão da verdade como elevação e fazer aparecer a contradição que se desdobra na imanência da enunciação ${ }^{3}$. Por isto, para Lacan (1954-1955), o sujeito é necessariamente divido entre enunciado e enunciação, entre o conteúdo intencional de sua fala e a maneira como esta é inscrita no Outro.

Desta forma, podemos dizer que o mundo dionisíaco da tragédia Grega não é exatamente abolido em Platão, como argumentam Nietzsche (1992) e Deleuze (1968), mas ganha uma nova determinação. Ele torna-se, antes, drama do conceito, das relações entre o símbolo e o ser. O interesse, o sucesso da filosofia platônica reside no ponto em que, segundo seus próprios critérios explícitos, ela fracassa. Como no drama trágico Grego, tal fracasso ainda não é interpretado ou, dizendo em termos hegelianos, ele não é consciente-de-si, ainda não se tornou plenamente Conceito (HEGEL, 2011). Ainda subsiste um resquício de realidade no empreendimento platônico de tornar a razão imanente ao real. Isto é, Platão ainda reserva um lugar, no edifício ontológico, para aquilo que não é racional, aquilo que deve ser purgado do conceito de razão como imanência entre o Um e o Ser. O nome deste resto de realidade que emperra a transcendência da Ideia, é claro, é simulacro. E o recuo de Platão frente à força do conceito pode ser relacionado à impotência da Ideia não apenas em mediar, mas também em deixar-se mediar, pelo não ser do simulacro.

Por isto as inversões, as impossibilidades que permeiam o discurso platônico ainda são "trágicas". Elas atingem seu discurso como que vindas de fora, de um Outro ainda não imanente ao próprio Um do conceito. Ora, esta era a ideia freudiana a respeito do sintoma: algo que não é reconhecido simbolicamente termina por retornar no próprio simbólico. $\mathrm{O}$ escândalo ontológico da correlação entre o Um e o não ser atinge a filosofia platônica como um estranho, um intruso que invade o palco, estragando o espetáculo quando, à revelia de suas melhores intenções, Platão se confronta com a monstruosidade de sua própria criação. $\mathrm{O}$ 
simulacro, o não ser, é o Um, não na forma de uma participação imperfeita, de um não ser apenas relativo ao Ser do Um, mas no coração mesmo do Um, dividindo-o. É tal espanto que aparece, então, nos diálogos do meio período, o Parmênides (2009) e no Sofista (2007), embora a título de uma hipótese extravagante sobre o não ser do Um.

Se Édipo realiza o crime, a hybris, a despeito de suas melhores intenções e fugindo da predição do oráculo de Delfos, no Parmênides Platão descobre que, ao colocar o Um no centro de sua ontologia, ele termina por assassiná-lo, mas sem saber que, com isto, lhe fornecia outra vida "monstruosa". Se no caso do drama de Sófocles trata-se do conflito entre a ação humana de Édipo e a Lei divina representada pelo oráculo de Delfos, no segundo já se trata do conflito imanente à própria razão, do conflito substancial à universalidade da razão como forma pura do ser. É que, ao se universalizar, a forma gera um conteúdo "patológico", uma exceção que, permanecendo excessiva, é também interna. Assim como, em Lacan (1973), é a universalidade da ordem simbólica que gera o objeto pequeno a e o real como encarnações da impossibilidade lógica do todo, o gozo nascido da impossibilidade da forma.

\title{
SIMULACRUM AND IDEIA FROM PLATO TO PSYCHOANALYSIS
}

\begin{abstract}
We seek in this paper to develop the question of the Platonic alliance of Freudian and Lacanian psychoanalysis. Thus, our first task is to question the image of Plato as dogmatic philosopher, concerned about the transcendence of the Ideia and ignoring sensitive singularity. On the contrary, we'll look that is through an immanent contradiction in the Platonic philosophy that we can understand how psychoanalysis can be affiliated with the Platonic project, but only if we admit the truth of Plato's discourse appears in its inherent flaws. We will seek to delineate the space of truth in psychoanalysis as being caused by the encounter with what Lacan called the real, trying to understand the relationship between the real with Platonism. Our goal is to question the anti-Platonism which constitutes the social and philosophical paradigm of the modern world, seeking in Plato and psychoanalysis ways to question the fantasy.
\end{abstract}

Keywords: Plato; psychoanalysis; truth; real.

\section{SIMULACRO Y IDEA DE PLATON A LA PSICOANÁLISIS}

\section{Resumen}

Buscamos en este trabajo desarrollar la cuestión de la filiación platónica del psicoanálisis freudiano y lacaniano. Para lo tanto, nuestra primera tarea es cuestionar la imagen de Platón como filósofo dogmático, preocupado con la trascendencia de la Idea y ignorando los derechos de la singularidad sensible. Por el contrario, veremos como és mediante una contradicción inmanente a la filosofía platónica que podemos entender cómo el psicoanálisis 
puede ser afiliada con el proyecto platónica, pero sólo si admitimos que la verdad del discurso de Platón aparece en sus fracasos inherentes. Vamos a tratar de delimitar el espacio de la verdad en el psicoanálisis como causado por el encuentro con lo que Lacan llama de real, tratando de entender la relación del real con el platonismo. Nuestro objetivo es cuestionar la lucha contra el platonismo que es el paradigma social y filosófico del mundo moderno, buscando en Platón y en la psicoanálisis formas con las quales cuestionar el fantasma.

Palabras clave: Platon; psicoanálisis; verdade; real.

\section{Referências}

BADIOU, A. (1988) O ser e o evento. Rio de Janeiro: Jorge Zahar editor. . Manifesto for philosophy (1992). New York: State University of New York

Press.

Logiques des Mondes - L'Être et l'Événement, 2 (2006). Paris: Seuil.

DELEUZE, G. (1968/2006) Diferença e repetição. Rio de janeiro: Graal.

FREUD, S. (1900/2006). A interpretação dos sonhos. Edição Standard Brasileira das Obras Psicológicas Completas de Sigmund Freud. v. III. Rio de Janeiro: Imago. (1915/2006). O recalque. In. A História do Movimento Psicanalítico - Artigos sobre a Metapsicologia - Outros trabalhos. Edição Standard Brasileira das Obras Psicológicas Completas de Sigmund Freud. v. XIV. Rio de Janeiro: Imago.

GARCIA-ROSA, L.A. (2009) Freud e o inconsciente. Rio de janeiro: Jorge Zahar editor. HEGEL, G-W-F. (1997) Princípios da filosofia do direito. São Paulo: Martins Fontes. . (2011) Ciência da lógica. São Paulo: Barcarolla.

HEIDEGGER, M. (1995) Ser e Tempo (parte I). Petrópolis: Vozes.

Lacan, J. (1949/1998). O estádio do espelho como formador da função do eu. In. Escritos. Rio de Janeiro: Zahar.

(1954-1955/1987). O seminário livro 2: O eu na teoria de Freud e na técnica da psicanálise. Rio de Janeiro: Jorge Zahar.

. (1956/1998) A coisa freudiana. In. Escritos. Rio de Janeiro: Jorge Zahar.

(1959-1960/1999). O seminário, livro 7. A ética da psicanálise. Rio de Janeiro: Jorge

Zahar.

(1962-1963/2005). O Seminário, livro 9. A angústia. Rio de Janeiro: Jorge Zahar. (1966/1998) A ciência e a verdade. In. Escritos. Rio de Janeiro: Jorge Zahar. 
(1968/2003). Proposição de 9 de outubro de 1967 sobre o psicanalista da Escola.

In. Outros escritos. Rio de Janeiro: Jorge Zahar.

. (1972-1973/2012). O seminário, livro 19: Ou pior... Rio de janeiro: Jorge Zahar.

(1972-1973/2008). O seminário, livro 20: Mais, ainda. Rio de Janeiro: Jorge

Zahar.

(1973/2003). O aturdito. In. Outros escritos. Rio de Janeiro: Jorge Zahar.

MILLER, J-A. (2011) Perspectiva dos escritos e outros escritos de Lacan. Entre o desejo e gozo. Rio de Janeiro: Jorge Zahar.

NIETSZCHE, F. (1992) Além do bem e do mal. São Paulo: Companhia das letras.

PLATÃO. (1993) A República. Lisboa: Fundação Calouste Gulbenkian.

.(2003) Mênon. São Paulo: Loyola.

. (2007) Diálogos I: Teeteto (ou do conhecimento), Sofista ( ou do ser), Protágoras( ou

sofistas). Bauru, SP: EDIPRO.

(2009) Diálogos IV. Parmênides (ou Das formas), Político (ou da Realeza), Filebo

(ou do Prazer), Lísis (ou da Amizade). Bauru, SP: EDIPRO.

RANCIÉRE, J. (2007) O mestre ignorante: Cinco lições sobre a emancipação intelectual.

Belo Horizonte: Autêntica.

SAFATLE, V. (2008) Cinismo e falência da crítica. São Paulo: Boitempo.

ZIZEK, S. (2013) Menos que nada-Hegel e a sombra do materialismo dialético. São Paulo:

Boitempo editorial.

Data de recebimento: $26 / 10 / 16$

Data de aceite: $23 / 03 / 17$

\section{Sobre o autor:}

Pedro Sobrino Laureano é Professor assistente do dpto. de psicologia (DPSIC) da Universidade Federal de São João del Rei. Endereço Eletrônico: pedro@laureanopsi.com.br

\footnotetext{
${ }^{1}$ Aqui podemos observar uma mudança social e política na função do analista. Este, anteriormente tido como suposto saber, como mestre que detêm a Verdade do sujeito, agora passa a ser cada vez mais associado àquilo que Lacan chama de "pequeno outro", o parceiro imaginário que permitirá ao sujeito gozar (Lacan, 1949/1998). O analista, então, aproxima-se da perspectiva "liberal" que permite que tudo seja dito e nada proíbe no que diz respeito à liberdade de expressão, permitindo a relativização das proibições simbólicas que constrangem o autodesenvolvimento pessoal. Ora, o papel do analista é, para Freud, justamente o inverso: certamente, trata-se de relativizar as interdições simbólicas, mas para se atingir o ponto em que a interdição e a Lei dão lugar à impossibilidade.
} 


\footnotetext{
${ }^{2} \mathrm{O}$ recalque propriamente dito, aquele que estrutura os sintomas é, então, uma defesa contra o recalque original. Sua função principal não é proibir o prazer, mas manter a crença de que, para além da proibição, haveria um prazer não mediado pela linguagem. É deste prazer a mais, proibido ou perdido, que o sujeito goza.

${ }^{3} \mathrm{O}$ que, mais uma vez, pode aproximar a psicanálise de Hegel. Basta lembrar de asserções como estas, em que Hegel explicita a contradição como desdobramento interior da coisa em seu avesso: "Em tal determinação está presente em si e para si o oposto dela mesma e, sem voltar para a natureza da questão e apelar para ela, aquela determinação de reflexão tem de ser confundida nela mesma, pelo fato de que é tomada tal como se oferece, e seu outro é nela mesma demonstrado. Seria um esforço inútil querer, por assim dizer, captar todas as nuances e os caprichos da reflexão e de seu modo de raciocinar, a fim de subtrair-lhes e tornar impossível seus impasses e desvios, mediante os quais ela oculta sua contradição diante de si mesma“"(Hegel, 2011, p. 84).
} 